\title{
Diet of crab-eating fox, Cerdocyon thous (Linnaeus) (Carnivora, Canidae), in a suburban area of southern Brazil
}

\author{
Ezequiel Pedó ${ }^{\text {;; }}$ Ana C. Tomazzoni ${ }^{\text {1; }}$ Sandra M. Hartz ${ }^{1} \&$ Alexandre U. Christoff ${ }^{2}$ \\ ${ }^{1}$ Laboratório de Ecologia de Populações e Comunidades, Departamento de Ecologia, Instituto de Biociências, Universidade \\ Federal do Rio Grande do Sul. Caixa Postal 15007, 91501-970 Porto Alegre, Rio Grande do Sul, Brasil. \\ E-mail: ezequiel.pedo@gmail.com; actomazzoni@yahoo.com.br; hartzsm@ecologia.ufrgs \\ ${ }^{2}$ Departamento de Biologia, Museu de Ciências Naturais, Universidade Luterana do Brasil. 92420-280 Canoas, Rio Grande \\ do Sul, Brasil.E-mail: auchrist@ulbra.br
}

\begin{abstract}
The crab-eating fox, Cerdocyon thous (Linnaeus, 1766), is a small canid with twilight and nocturnal habits from savannas and forests of South America. In this study, we seasonally determined and quantified the diet of $C$. thous in Lami Biological Reserve, a conservation unit with 179.78ha situated in a suburban area in the municipality of Porto Alegre, southern Brazil. During the year 2000, we collected 80 fecal samples -20 for each season - in two or three week sampling intervals, along trails inside the Reserve. Samples were dried in an oven for $24 \mathrm{~h}$ at $60^{\circ} \mathrm{C}$, immersed in $70 \%$ alcohol, and prey items were identified using a stereomicroscope. The diet of the crab-eating fox was essentially carnivorous ( $87.62 \%$ composed by vertebrates), with seasonal variation ( $p=$ 0.0009 ) and absence of fruits. Small non-flying mammals and birds were the most frequent prey, being proportionally more preyed in autumn and summer, respectively. Arthropods were more preyed in winter and spring and bird/reptile eggs only in summer and spring, in the reproduction period of these groups.
\end{abstract}

KEY WORDS. Canids; food habits; Rio Grande do Sul; seasonality; South America.

\begin{abstract}
RESUMO. Dieta de graxaim-do-mato, Cerdocyon thous (Linnaeus) (Carnivora, Canidae), em uma região suburbana do sul do Brasil. O graxaim-do-mato, Cerdocyon thous (Linnaeus, 1766), é um canídeo de pequeno porte de hábito crepuscular e noturno que ocorre nas savanas e florestas da América do Sul. Neste estudo foi avaliada a sazonalidade e a dieta de $C$. thous na Reserva Biológica do Lami, uma unidade de conservação com 179,78ha, situada na região suburbana do município de Porto Alegre, no sul do Brasil. Durante o ano de 2000 foram coletadas 80 amostras fecais - 20 por estação do ano - em coletas realizadas a cada duas ou três semanas, percorrendo as trilhas existentes na Reserva. As amostras foram desidratadas em estufa por $24 \mathrm{~h}$ a $60^{\circ} \mathrm{C}$, imersas em álcool a $70 \%$, e as presas foram identificadas com auxílio de estereomicroscópio. A dieta do graxaim-do-mato apresentou-se essencialmente carnívora $(87,62 \%$ composta por vertebrados), com variação sazonal $(p=0,0009)$ e ausência de frutos. Pequenos mamíferos não-voadores e aves foram os itens mais freqüentes, sendo proporcionalmente mais predados no outono e no verão, respectivamente. Artrópodos foram mais predados no inverno e na primavera e ovos de aves e/ou répteis somente no verão e na primavera, período de reprodução nestes dois grupos.
\end{abstract}

PALAVRAS-CHAVE. América do Sul; canídeos; hábitos alimentares; Rio Grande do Sul; sazonalidade.

Animal trophic ecology can provide relevant information for conservation programs. Feeding permeates several aspects of species biology, as habitat preferences, morphological and physiological adaptations, behavioral aspects and interactions with other species. The crab-eating fox, Cerdocyon thous (Linnaeus, 1766), is a small canid with body mass between 4 and 13kg (Moehlman 1986, Motta-Junior et al. 1994). It presents twilight and nocturnal habits, with extensive distribution in the savannas and forests of South America, from Uruguay and northern Argentina to northern of South American continent (Berta 1987, Medel \& Jaksic 1988, EIsenberg \& Redford 1999). Its predation strategy is opportunistic, with an omnivore diet, including mainly small mammals, birds, insects and fruits, and consuming the most abundant food resources in each season (Bisbal \& OJASTi 1980, Berta 1987, MotTa-Junior et al. 1994). In southern Brazil, the crab-eating fox is probably the carnivore species that lives closest to man, bringing itself benefits (it sometimes feeds on human food, domestic animals, carrion) and injuries (many die overruned and suffer man persecution) (DотTо et al. 2001). 
The objective of this study is to present quali-quantitative information on food items and to check for the existence of seasonallity in the diet of crab-eating foxes in the Lami Biological Reserve.

\section{MATERIALS AND METHODS}

\section{Study area}

Field work was conducted in the Lami Biological Reserve $\left(30^{\circ} 15^{\prime} \mathrm{S}, 51^{\circ} 05^{\prime} \mathrm{W}\right)$, located in the suburban zone of Porto Alegre municipality, in Rio Grande do Sul State. The reserve presents a total area of 179.78ha (BRACK et al. 1992). This area is localized in Savannah/ Seasonal Semideciduous Forest contact (TeIXeIRA \& Coura-NeTo 1986), encompassing a mosaic of wetlands (wet grasslands and swamps), sandy coastal forest ("restinga"), semideciduous forest and water bodies, including a stream and a large lake that surrounds $60 \%$ of reserve perimeter.

The climate is characterized by four well-limited seasons, being characterized by high humidity (annual mean 76\%) and dry season absence. The annual mean temperature is $19.4^{\circ} \mathrm{C}$, with maximal temperature in January $\left(37.8^{\circ} \mathrm{C}\right)$ and minimal in July $\left(1.4^{\circ} \mathrm{C}\right)$. The annual mean precipitation is $1,324 \mathrm{~mm}$ (mean between years 1912 and 1997) (Livi 1998). Flooding occurs occasionally during the winter, particularly in areas bordered by the Guaíba Lake, probably because of a smaller evaporation rate during this period.

\section{Sampling}

During the year 2000, about 300 fecal samples were collected in field expeditions at two or three-week sampling intervals, along trails representing distinct vegetation types in the Lami Biological Reserve. From the 300 fecal samples, 80 were randomly sampled (20 for each season) and analyzed. It is important to point out that all days of field work were represented.

Sample scats were identified from their size, form, odor, presence of tracks in the immediate area and, eventually, by presence of hairs (identified by microscope). The absence of other similar wild canids with similar scats in the study area as Lycalopex gymnocercus (Fischer, 1814), a sympatric species in Rio Grande do Sul - reduced uncertainty in the identification. Scats of doubtful origin were discarded. We dried the samples in an oven at $60^{\circ} \mathrm{C}$ for $24 \mathrm{~h}$, immersed them in $70 \%$ alcohol and identified food items under a stereomicroscope (adapted from KorsChgen 1987).

\section{Data analysis}

To describe the diet of the crab-eating foxes, data were analyzed using the percentage of occurrence frequency (OF\% proportion of the total number of samples in which a certain food item is present) and percentage of relative frequency (RF\% - proportion of a food item in relation to all food items in the sample). The seasons were statistically analyzed by the contingency data of presence or absence (binary data) of food items in 80 fecal samples. To compare the diet between seasons, resemblance measures and analysis of variance with randomization testing (hypothesis test) were applied to explore variation in the data, as proposed by PILlar \& ORLócI (1996), using a multivariate statistics software, MULTIV, 2.1.1 version (Pillar 2001). The analisys of variance involves a division of total variation in "between groups" and "within groups" (PILlar \& Orlóci 1996). The objective of this division was to evaluate the variation magnitude "between groups" and if groups are different or not, through a probability obtained with a randomization testing. The division was realized through sum of squares of Euclidean distance between sampling units. The randomization testing produces a probability (QbNull $\geq \mathrm{Qb}$, the null sum of squares is larger or equal than the sum of squares observed), and the Null Hypothesis $\left(\mathrm{H}_{0}\right)$ is rejected when probability is lesser or equal than $\alpha$ (0.1). The Null Hypothesis $\left(\mathrm{H}_{0}\right)$ stated that there is not significant difference in the diet of the crab-eating fox between the seasons of the year 2000 in Lami Biological Reserve. To test the hypothesis, 10,000 iterations were applied.

\section{RESULTS AND DISCUSSION}

Eighteen taxa were identified in the diet of the crab-eating fox (Tab. I). This number is underestimated because some taxa were not possible to identify to species level. The diet of the crab-eating fox was essentially carnivorous $(87.62 \%$ of the diet was composed by vertebrates), a higher proportion than previously reported. The most similar data was reported in a study at the Colombian Andes, where $68.9 \%$ of the diet of crabeating foxes was composed by vertebrates (DELGADO-V 2002). In other studies with this species, the percentage of vertebrates in the diet was always lower: Venezuela, 58\% (BISBAL \& OJASTI 1980); in Brazilian Cerrado, 49.9\% (Juarez \& Marinho-Filho 2002); and in an altitudinal forest in southeastern Brazil, $34.23 \%$ (FACURE et al. 2003). In study sites with similar conditions urban influence - the diet of the crab-eating fox was composed by $43.86 \%$ (MotTa-Junior et al. 1994) and $41.20 \%$ (FACURE \& Monteiro-Filho 1996) of vertebrates, and the species was classified as omnivorous.

Small rodent species were the most important food item in the diet of the crab-eating fox at the Lami Biological Reserve, with a $52.8 \%$ relative frequency, including at least seven species. These species have distinct habits, from open areas, as Cavia aperea Erxleben, 1777, to semi-aquatic - Holochilus brasiliensis (Desmarest, 1819), cursorial of forest and open areas - Akodon sp., semi-arboreal - Oligoryzomys sp., arboreal - Phyllomys dasythrix Hensel, 1872, semi-fossorial of forest and open areas Oxymycterus sp., and peridomiciliary, like Mus musculus Linnaeus, 1758 . This variety of prey habits indicates that crab-eating foxes are versatile predators. Occurrence of an arboreal species $(P$. dasythrix) in the diet could be explained by its eventual movement in the ground or due to the ingestion of this prey previously dead (by disease or attack of other predators, like birds of prey, etc.). It is important to note that the carnivorous habits of the local crab-eating foxes could be related to the absence of autochthonous felines, which are locally extinct. 
Table I. Diet of the crab-eating fox (Cerdocyon thous) in Lami Biological Reserve, southern Brazil, during the year $2000(\mathrm{~N}=80$ fecal samples, 20 per season).

\begin{tabular}{|c|c|c|c|c|c|}
\hline \multirow{2}{*}{ Food items } & \multicolumn{5}{|c|}{ Occurrence frequency (Relative frequency) (\%) } \\
\hline & Summer & Autumn & Winter & Spring & Total \\
\hline \multicolumn{6}{|l|}{ Plants } \\
\hline Bryophyta & $0(-)$ & $0(-)$ & $0(-)$ & $10(-)$ & $2.5(-)$ \\
\hline Grasses (Graminae e Ciperaceae) & $45(-)$ & $35(-)$ & $25(-)$ & $25(-)$ & $32.5(-)$ \\
\hline Mimosoideae (Leguminosae) & $10(-)$ & $45(-)$ & $10(-)$ & $35(-)$ & $25(-)$ \\
\hline Plants NI & $40(-)$ & $75(-)$ & $35(-)$ & $80(-)$ & $57.5(-)$ \\
\hline Arthropods NI & $0(0)$ & $0(0)$ & $0(0)$ & $5(1.64)$ & $1.25(0.56)$ \\
\hline \multicolumn{6}{|l|}{ Insects } \\
\hline Coleoptera & $5(2.56)$ & $5(2.70)$ & $15(7.32)$ & $15(4.92)$ & $10(4.49)$ \\
\hline Lepidoptera & $0(0)$ & $0(0)$ & $0(0)$ & $10(3.28)$ & $2.5(1.12)$ \\
\hline Hemiptera & $0(0)$ & $0(0)$ & $0(0)$ & $5(1.64)$ & $1.25(0.56)$ \\
\hline Hymenoptera & $0(0)$ & $0(0)$ & $0(0)$ & $5(1.64)$ & $1.25(0.56)$ \\
\hline Insects NI & $0(0)$ & $0(0)$ & $5(2.44)$ & $0(0)$ & $1.25(0.56)$ \\
\hline \multicolumn{6}{|l|}{ Fishes } \\
\hline Cichlidae & $0(0)$ & $0(0)$ & $0(0)$ & $5(1.64)$ & $1.25(0.56)$ \\
\hline Fishes $\mathrm{NI}$ & $5(2.56)$ & $0(0)$ & $0(0)$ & $0(0)$ & $1.25(0.56)$ \\
\hline \multicolumn{6}{|l|}{ Reptiles } \\
\hline Testudines & $0(0)$ & $10(5.41)$ & $0(0)$ & $15(4.92)$ & $6.25(2.81)$ \\
\hline \multicolumn{6}{|l|}{ Birds } \\
\hline Dendrocygna viduata (Linnaeus, 1766) & $5(2.56)$ & $0(0)$ & $0(0)$ & $5(1.64)$ & $2.5(1.12)$ \\
\hline Passeriformes & $0(0)$ & $0(0)$ & $0(0)$ & $5(1.64)$ & $1.25(0.56)$ \\
\hline Birds NI & $40(20.51)$ & $15(8.11)$ & $35(17.07)$ & $55(18.03)$ & $36.25(16.30)$ \\
\hline \multicolumn{6}{|l|}{ Mammals } \\
\hline Cavia aperea Erxleben, 1777 & $0(0)$ & $15(8.11)$ & $0(0)$ & $0(0)$ & $3.75(1.69)$ \\
\hline Phyllomys dasythrix Hensel, 1872 & $0(0)$ & $5(2.70)$ & $15(7.32)$ & $20(6.56)$ & $10(4.49)$ \\
\hline Akodon sp. & $25(12.82)$ & $25(13.51)$ & $5(2.44)$ & $20(6.56)$ & $18.75(8.43)$ \\
\hline Holochilus brasiliensis (Desmarest, 1819) & $20(10.26)$ & $30(16.22)$ & $5(2.44)$ & $40(13.11)$ & $23.75(10.67)$ \\
\hline Oligoryzomys sp. & $30(15.38)$ & $30(16.22)$ & $50(24.39)$ & $30(9.84)$ & $35(15.73)$ \\
\hline Oxymycterus sp. & $0(0)$ & $5(2.70)$ & $0(0)$ & $0(0)$ & $1.25(0.56)$ \\
\hline Mus musculus Linnaeus, 1758 & $5(2.56)$ & $0(0)$ & $0(0)$ & $0(0)$ & $1.25(0.56)$ \\
\hline Cricetidae/Muridae NI & $15(7.69)$ & $20(10.81)$ & $25(12.20)$ & 35 (11.48) & $23.75(10.67)$ \\
\hline Didelphidae NI & $10(5.13)$ & $0(0)$ & $0(0)$ & $0(0)$ & $2.5(1.12)$ \\
\hline Small non-flying mammals NI & $25(12.82)$ & $15(8.11)$ & $40(19.51)$ & $15(4.92)$ & $23.75(10.67)$ \\
\hline Bird/reptile eggs & $5(2.56)$ & $0(0)$ & $0(0)$ & $5(1.64)$ & $2.5(1.12)$ \\
\hline Items $\mathrm{NI}$ & $5(2.56)$ & $10(5.41)$ & $10(4.88)$ & $15(4.92)$ & $10(4.49)$ \\
\hline
\end{tabular}

The identification of some rodents to species level (as C. aperea, P. dasythrix, H. brasiliensis and M. musculus) was possible because only one species of each genus occurs in the region. Molar teeth in the samples allowed identification only to generic level. The following references were used for determining rodent species: EMmONs et al. (2002) for P. dasythrix, CHRISTOFF et al. (2000) for akodon sp., Hershrovitz (1955) for H. brasiliensis, Carleton \& Musser (1989) for Oligoryzomys sp., Hershkovitz (1994) for Oxymycterus sp. and EISENBERG \& REDFORD (1999) for M. musculus.

Absence of fruits, an important resource mentioned in the literature (Bisbal \& OJASTI 1980, MotTA-Junior et al. 1994, PAZ et al. 1995, Facure \& Giaretta 1996, Facure \& Monteiro-Filho 1996, Facure et al. 2003, MacDonald \& Courtenay 1996), could be associated to a particular characteristic of the local population of crab-eating foxes, which aggregates efforts and directs skills to prey on small mammals, only occasionally feeding on fruits. Only in the year 2001, consequently after this study, 
scats (three) of crab-eating fox were found containing fruits of palm trees: Syagrus romanzoffiana (Cham.) Glassm. and Butia capitata (Mart.) Becc. MotTA-Junior et al. (1994) described the crab-eating fox as potential seed disperser by endozoochory for many fructiferous plant species they consumed, and PAZ et al. (1995) reported this species as a great consumer and a probable disperser of a palm tree species (B. capitata) in Uruguay. However, through a field test with Lycalopex culpaeus (Molina, 1782), Bustamante et al. (1992) affirmed that foxes are inefficient and possibly ineffective dispersers because they defecate viable seeds where germination is unlikely to be successful.

During the bird reproductive season (spring and summer) the bird migration from other regions of the continent occurs to nest in the Lami Biological Reserve (Albuquerque et al. 1986, Tomazzoni et al. 2004). Birds were more frequent in the diet during this period, probably because of crab-eating fox predation on nestlings, resource that not seem to be so available in other seasons.

Other prey resources available to the crab-eating fox frogs, snakes and lizards - were not observed in the sample, although they are relatively abundant in the study area. The crab-eating fox, however, preyed a large number of turtle eggs during spawning and incubation period. The local turtle species (Testudines) lay eggs in the warmer months, spring and summer (Bujes 1998). However, evaluating the amount of preyed eggs from fecal contents yields underestimated values.

Plants occurred in the diet only as vegetative parts, except by some Gramineae seeds. They are considered food items because it is possible that they aid food digestion (DIETz 1984). However, they are not included in the diet analysis because they do not have nutritional value if compared to other preys (MacDonald \& Courtenay 1996).

The randomization testing indicated the occurrence of seasonal variation in the diet ( $p=0.0009$ between groups), but contrasts between summer/winter and autumn/spring were not significant (Tab. II). Nevertheless, greater incidence of some food items was observed in some seasons (arthropods in winter and spring, birds and bird/reptile eggs in summer and spring, small non-flying mammals in autumn). Other studies in which diet of the crab-eating fox was observed to be seasonally variable (Brady 1979, Bisbal \& OJasti 1980, Motta-Junior et al. 1994, FACURE et al. 2003), comparisons were made between dry and wet seasons.

According to the results, during the year 2000 the crabeating foxes of the Lami Biological Reserve presented a carnivorous and seasonally variable diet, acted predominantly as predators of small mammal populations and could not be considered potential seed dispersers.

\section{ACKNOWLEDGEMENTS}

To João A. Jarenkow (UFRGS) for help in the identification of plant items, Fábio S. Vilella (UFRGS) for the identification of fish scales, Roberto B. de Oliveira (Museu de Ciências e
Table II. Results of analysis of variance with randomization testing applied for multivariate data of food items, comparing the seasons of the year 2000 for crab-eating fox (Cerdocyon thous) diet in the Lami Biological Reserve, southern Brazil, during the year 2000 (20 samples per season, 10,000 iterations, $(=0.1)$.

\begin{tabular}{lcc}
\hline \multicolumn{1}{c}{ Seasons } & Sum of squares $(\mathrm{Q})$ & $\mathrm{P}(\mathrm{QbNull}>=\mathrm{Qb})$ \\
\hline Between groups & 13.687 & 0.0009 \\
Summer-Autumn & 4.275 & $0.0432^{*}$ \\
Summer-Winter & 2.375 & 0.4576 \\
Summer-Spring & 5.075 & $0.0150^{*}$ \\
Autumn-Winter & 5.900 & $0.0044^{*}$ \\
Autumn-Spring & 3.300 & 0.1738 \\
Winter-Spring & 6.450 & $0.0016^{*}$ \\
Within groups & 178.950 & \\
\hline Total & 192.640 \\
\hline
\end{tabular}

*Values that rejected null hypothesis $\left(\mathrm{H}_{0}\right)$, indicating that differences between seasons are significant.

Tecnologia da Pontifícia Universidade Católica do Rio Grande do Sul - MCT/PUCRS) for the identification of reptile scales and Glayson A. Bencke (Museu de Ciências Naturais da Fundação Zoobotânica do Rio Grande do Sul - MCN/FZBRS) for the identification of bird feathers. Andreas Kindel, João C.P. Dotto, Fernando G. Becker, Kátia G. Facure, Cory T. de Carvalho and an anonymous reviewer provided comments to the article. Fundação de Amparo à Pesquisa do Rio Grande do Sul (FAPERGS) provided financial support to the first author.

\section{REFERENCES}

Albuquerque, E.P.; S.L. Reinehr \& L. Verrastro. 1986. Lista preliminar das aves observadas na área da Reserva Biológica do Lami e Ponta do Cego, Porto Alegre, RS, Brasil. Roessleria, Porto Alegre, 8: 186-196.

BERTA, A. 1987. Origin, diversification, and zoogeography of the South American Canidae, p. 455-471. In: B.D. PATTERson \& R.M. TIмм (Eds). Studies in neotropical mammalogy: essays in honor of Philip Hershkovitz. Chicago, Fieldiana Zoology New Series, vol. 39, 506p.

Bisbal, F.J. \& J.D. Ojasti. 1980. Nicho trófico del zorro Cerdocyon thous (Mammalia, Carnivora). Acta Biologica Venezuelica, Caracas, 10 (4): 469-496.

Brack, P.; J.C. Prates \& M.F.M. Santos. 1992. Guia de campo: espécies da Reserva Biológica do Lami. Porto Alegre, Secretaria Municipal do Meio Ambiente, 38p.

BRADY, C.A. 1979. Observations on the behavior and ecology of the crab-eating fox (Cerdocyon thous), p. 161-171. In: J.F. EISENBERG (Ed.). Vertebrate ecology in the northern Neotropics. Washington, Smithsonian Institution Press, 271p.

Bujes, C.S. 1998. Atividade de nidificação de Phrynops hilarii Duméril et Bibron (Testudines, Chelidae) na Reserva Biológica do Lami, Rio Grande do Sul, Brasil. Revista Brasileira

Revista Brasileira de Zoologia 23 (3): 637-641, setembro, 2006 
de Zoologia, Curitiba, 15 (4): 921-928.

Bustamante, R.O.; J.A. Simonetti \& J.E. Mella. 1992. Are foxes legitimate and efficient seed dispersers? A field test. Acta Oecologica, Montrouge, 13 (2): 203-208.

Carleton, M.D. \& G.G. Musser. 1989. Sistematic studies of oryzomyine rodents (Muridae, Sigmodontinae): a synopsis of Microryzomys. Bulletin of the American Museum of Natural History, New York, 191: 1-83.

Christoff, A.U.; V. Fagundes; I.J. Sbalqueiro; M.S. Mattevi \& Y. Yonenaga-Yassuda. 2000. Description of a new species of Akodon (Rodentia: Sigmodontinae) from southern Brazil. Journal of Mammalogy, Lawrence, 81 (3): 838-851.

Delgado-V, C.A. 2002. Food habits and habitat of the Crabeating fox Cerdocyon thous in the highlands of eastern Antioquia, Cordillera Central, Colombia. Mammalia, Paris, 66 (4): 599-602.

DiETz, J.M. 1984. Ecology and social organization of the maned wolf (Chrysocyon brachyurus). Smithsonian Contributions to Zoology, Washington, 392: 1-51.

Dotto, J.C.P.; M.E. Fabián \& J.O. Menegheti. 2001. Atuação de Pseudalopex gymnocercus (Fischer, 1814) e de Cerdocyon thous (Linnaeus, 1766) (Mammalia, Canidae) como fator de mortalidade de cordeiros no sul do Brasil. Boletín de la Sociedad de Biología de Concepción, Concepción, 72: 51-58.

EIsenberg, J.F. \& K.H. RedFord. 1999. Mammals of the Neotropics. Chicago, University of Chicago Press, vol. 3, 609p.

Emmons, L.H.; Y.L.R. Leite; D. Koск \& L.P. Costa. 2002. A review of the named forms of Phyllomys (Rodentia: Echimyidae) with the description of a new species from coastal Brazil. American Museum Novitates, New York, 3380: 1-40.

FACURE, K.G. \& A.A. GiaretTA. 1996. Food habits of carnivores in a coastal Atlantic Forest of southeastern Brazil. Mammalia, Paris, 60 (3): 499-502.

Facure, K.G. \& E.L.A. Monteiro-Filho. 1996. Feeding habits of the crab-eating fox, Cerdocyon thous (Carnivora, Canidae), in a suburban area of southeastern Brazil. Mammalia, Paris, 60 (1): 147-149.

Facure, K.G.; A.A. Giaretta \& E.L.A. Monteiro-Filho. 2003. Food habits of the crab-eating fox, Cerdocyon thous, in an altitudinal forest of the Mantiqueira Range, southeastern Brazil. Mammalia, Paris, 67 (4): 503-511.

Hershrovitz, P.M. 1955. South American marsh rats, genus Holochilus, with a summary of sigmodont rodents. Fieldiana Zoology, Chicago, 37: 639-687.

Hershrovitz, P.M. 1994. The description of a new species of south american hocicudo, or long-nose mouse, genus Oxymycterus (Sigmodontinae, Muroidea), with a critical review of the generic content. Fieldiana Zoology, Chicago, 79: 1-43.

Juarez, K.M. \& J. Marinho-Filho. 2002. Diet, habitat use, and home ranges of sympatric canids in central Brazil. Journal of Mammalogy, Lawrence, 83 (4): 925-933.

Korschgen, L.J. 1987. Procedimientos para el analisis de los hábitos alimentarios, p. 119-134. In: R.R. TARRÉs (Ed.). Manual de técnicas de gestión de vida silvestre. Maryland, WWF, $\mathrm{X}+703 \mathrm{p}$.

Livi, F.P. 1998. Elementos do clima: o contraste de tempos frios e quentes, p. 73-78. In: R. Menegat; M.L. Porto; C.C. Carraro \& L.A.D. Fernandes (Eds). Atlas Ambiental de Porto Alegre. Porto Alegre, Editora da Universidade Federal do Rio Grande do Sul, 256p.

MacDonald, D.W. \& O. Courtenay. 1996. Enduring social relationships in a population of crab-eating zorros, Cerdocyon thous, in Amazonian Brazil (Carnivora, Canidae). Journal of Zoology, London, 239: 329-355.

Medel, R.G. \& F.M. Jaksic. 1988. Ecología de los cánidos sudamericanos: una revisión. Revista Chilena de Historia Natural, Santiago, 61: 67-79.

Moenlman, P.D. 1986. Ecology of cooperation in canids, p. 6486. In: D.I. Rubenstein \& R.W. Wranghan (Eds). Ecological aspects of social evolution: birds and mammals. Princeton, Princeton University Press, 564p.

Motta-Junior, J.C.; J.A. Lombardi \& S.A. Talamoni. 1994. Notes on crab-eating fox (Dusicyon thous). Seed dispersal and food habits in southeastern Brazil. Mammalia, Paris, 58 (1): 156-159.

Paz, E.A.; R. Rodríguez-Mazzini \& M. Clara. 1995. Dispersión de la "palma butiá" (Butia capitata) por el "zorro de monte" (Cerdocyon thous) en montes nativos de la Reserva de Biosfera, Bañados del Este, Uruguay. Comunicaciones Botanicas del Museo de Historia Natural de Montevideo, Montevideo, 104 (5): 1-4.

PILLAR, V.D. 2001. MULTIV versão 2.1.1: aplicativo para análise multivariada, testes de aleatorização e autoreamostragem. Porto Alegre, Departamento de Ecologia da Universidade Federal do Rio Grande do Sul.

Pillar, V.D. \& L. Orlóci. 1996. On randomization testing in vegetation science: multifactor comparisons of relevé groups. Journal of Vegetation Science, Grangärde, 7: 585-592.

Teixeira, M.B. \& A.B. Coura-Neto. 1986. Vegetação. As regiões fitoecológicas, sua natureza, seus recursos econômicos. Estudo fitogeográfico, p. 541-632. In: M.B. Teixeira; A.B. CouraNeto; V. Pastore \& A.L.R Rangel-Filho. (Eds). IBGE. Folha SH.22 Porto Alegre e parte das folhas SH.21 Uruguaiana e SI.22 Lagoa Mirim. Rio de Janeiro, IBGE, Levantamento de recursos naturais, vol. 33, 796p.

Tomazzoni, A.C., E. Pedó \& S.M. Hartz. 2004. Food habits of Great Horned Owls (Bubo virginianus) in Lami Biological Reserve, southern Brazil. Ornitologia Neotropical, Montreal, 15: 279-282.

Received in 24.VIII.2005; accepted in 07.VIII.2006. 